\title{
Economic Structure and Services Efficiency of Turkish Beekeepers' Association
}

\author{
By Vedat Ceyhan*1, Selime Canan ${ }^{1}$, Çağatay Yıldırım ${ }^{1}$, Hatice Türkten ${ }^{1}$
}

\begin{abstract}
The study aimed to explore the current economic situation and services efficiency level of problems of beekeepers' union and honey producers' union in Turkey. Research data were collected from 73 beekeepers' union and 58 honey producers' union by using well-structured questionnaire. In the research, classical economic analysis approach was used to reveal socio-economic structure of unions. When measuring the efficiency, we followed two stage procedure. In first stage, data envelopment analysis was used, while Tobit model was used to explore the inefficiency determinants in second stage. Research results showed that typical Turkish beekeeper's union obtained the £1,59 from each expenditure by $€ 1$. Economic condition of beekeeping unions was healthier than that of honey producers' union. $11 \%$ of the Turkish beekeepers and honey producers' unions were efficient, while the rest were inefficient. The most critical variables affected the efficiency level of unions were manager's profile and the number of union member. Service efficiency level would increase, if the number of union member increased and profile of managers were improved. The research suggested that the typical Turkish beekeepers' union would have 927 members to be efficient if they had no income sources without member fee. Keeping the basic record in the beekeepers' association and developing information management system would accelerate the efficiency improving in Turkey.
\end{abstract}

Keywords: beekeeping, beekeepers' union, honey producers' union, economic analysis, service efficiency

\section{Introduction}

Human beings have maintained the honey bee colonies and produced honey together with hive products such as beeswax, pollen and royal jelly worldwide for 4500 years. Beekeeping is not only basic income sources but also such kinds of hobby or part time job for rural people all over the world due to less initial and working capital demand and having quick capital recovery. Beekeeping has also the contributions to the not only environmental sustainability and agricultural production via pollination, but also human health. Turkey is one of the main actors in world beekeeping industry due to having good ecological conditions that ensures the availability of flowers from lots of wild species and cultivated plants throughout the year, even if winter time in Turkey. Turkey ranks second of largest honey producing countries in the world and constituted the $8 \%$ of the total world colony and $6 \%$ of the world honey production. The contribution of beekeeping industry is approximately $\$ 330$ million to the Turkish economy. On the other hand, beekeeping has provided employment about 35 thousands of people in rural area (FAO, 2014). In last decades, pressure of increasing domestic and foreign demand to honey and other hive products has made Turkish beekeeping industry transform from small scale production unit to the modern and more commercial economic enterprise. Since the information related economic parameters of beekeeping sector in Turkey is

${ }^{1}$ University of Ondokuz Mayıs Faculty of Agriculture, Department of Agricultural Economics, 55139, Samsun, Turkey 
very scarce and fragmented, the economic dimension of the beekeeping enterprises and their association has come into the agenda for many traders and policy makers to develop economy without changing environmental balance. Therefore, exploring the economic structure of beekeepers' association and its efficiency level has become important issue in Turkey, like other main partners acting world beekeeping product market.

Up to now, several researches have conducted on beekeeping all over the world. Some of the previous researchers have focused on technical side of beekeeping, while the rest were interested in economic dimension of beekeeping. Researches related to the technical side of beekeeping have continued 6 different zones such as bee stocks, queen growth and colony life, bee product analysis, feeding, bee disease and pollination. However, the researches focused on the economic dimension of the beekeeping were relatively lesser than that of technical side. Most economic studies related to economic dimension of the beekeeping and beekeepers' association have been based on the macro level secondary data and outlined the general situation of beekeeping sector (Kizilaslan \& Kizilaslan, 2007, Pocol \& Ilea, 2008; Mogni, Senessi, Palau \& Vilella, 2010; Agera, 2011; Çakal, 2013). However, the studies based on beekeepers' level has been rare all over the world, as well as Turkey due to difficulties to reach healthy and detail data from beekeepers. Since reaching the beekeepers level data was difficult and required more time, most previous researchers have only concentrated on colony and production parameters by using the data specially belong the social variables of beekeepers ignoring the detail management data such as cost structure, marketing characteristics etc. (Yahaya \& Usman, 2008; Seven \& Yeninar, 2010; Pocol, 2011; Uzundumlu, Aksoy \& Iş1k, 2011; Popa \& Pocal, 2011; Masuku, 2013).

Unfortunately, there have been rare studies focusing on detailed economic analysis of beekeepers in the world (Singh \& Saxena, 2009; Barlovic, Kezic, Benedic, \& Grgic, 2009; Aiyeloja, Popoola, \& Ogunjinmi, 2010; Ćejvanovic, Grgic, Maksimović, \& Bicani, 2011; Popescu, 2013; Laate, 2013). Similarly, Turkish researchers have conducted some research by using detail beekeepers level management data (Saner, Yücel, Yercan, Karaturhan, Engindeniz, C,ukur, \& Kösoglu, 2011, Kekeçoğlu \& Rasgele, 2013, Kutlu, 2014).

The backgrounding of the literature showed that it was not clear that the economic performance and efficiency of beekeepers' association all over the world, as well as Turkey. Hence the research intended to test the differentiation of economic performance of beekeepers' association considering the ceteris paribus conditions. To reduce this information gap, the purposes of the study were (i) explore the economic structure of Turkish beekeepers' association, (ii) to calculate the services efficiency score of Turkish beekeepers' association and (iii) develop strategies and policy to increase efficiency of beekeepers' association.

\section{Materials and Methods}

\subsection{Research data}

Research data were collected from 131 beekeepers' association beekeepers, which was all the beekeepers' association in Turkey by using questionnaire. $56 \%$ of the 
total Turkish beekeepers' association were beekeeping unions (BU), while the rest were honey producers' union (HPU). Questionnaires were administered to the beekeepers' association to collect management data by considering the 2015 production year.

\subsection{Estimation of services efficiency}

Two-stage efficiency analysis procedure was followed when analyzing the services efficiency of beekeeper's associations. In first stage, services efficiency scores for Turkish beekeepers' association were estimated by using data envelopment analysis (DEA). The Farrell input-orientated measure of services efficiency was used; as Turkish beekeepers' association tend to have greater control over their inputs than they have over their outputs. The Farrell measure equals 1 for efficient Turkish beekeepers' association, and then decreases with inefficiency (Farrell, 1957). Based on the suggestion by Charnes, Cooper, \& Rhodes, (1978), we constructed DEA models for Turkish beekeepers' association assuming that each decision making unit (DMU), which is Turkish beekeepers' association in Turkey, marketing services and other services $\left(Y_{i}\right)$ using multiple inputs such as personal cost (Turkish Liras, €), asset (Turkish Liras, ‡), marketing cost (Turkish Liras, $€$ ) and education-extension cost (Turkish Liras, $€$ ) $\left({ }^{x_{i}^{*}}\right)$ and that beekeepers' association (i) was allowed to set its own set of weights for both inputs and output. Services were included the model as an index, which was constituted by aggregating the variables of number of education programs, number of consultation, number of beekeeper's level control and amount of inputs supplied to beekeepers. The data for all beekeepers' association were denoted by the $\mathrm{K} \times \mathrm{N}$ input matrix $(\mathrm{X})$ and $\mathrm{M} \times$ $\mathrm{N}$ output matrix (Y). Using piecewise technology, an input-oriented measure of efficiency can be calculated for the i-the beekeepers' association the solution to linear programming (LP):

Minimize $_{\theta, \lambda} \quad \theta$

Subject to

$-y i+Y \lambda \geq 0$

$\theta \mathrm{xi}-\mathrm{X} \lambda \geq 0$

$\lambda \geq 0$

where $\theta$ is the TE score having a value $0 \leq \theta \leq 1$. If the value equals 1 , the beekeepers' association is on the frontier; the vector $\lambda$ is an $N \times 1$ vector of weights which defines the linear combination of the peers of the $\mathrm{i}$-th beekeepers' association.

Coelli, Rao, O'Donnell, \& Battese, (2005) pointed out that the CRS model is only appropriate when the DMU is operating at an optimal scale. Factors such as imperfect competition and financial constraints may prevent a DMU from operating at optimal scale. Since beekeepers' association, as an DMU, in the research area conducted their activities under imperfect competition due to imperfect information about market such as input and output prices, and because the size of many beekeepers' association, made them ineligible for institutional loans, we transformed equation (1) to the variable returns-to scale (VRS) technology model by adding the convexity constraint: $\mathrm{N} 1 \boldsymbol{\lambda}=1$, where $\mathrm{N} 1$ is an $\mathrm{N} \times 1$ vector of ones and $\lambda$ is anNx1 vector of constant to the equation (1) based on suggestion by Banker, Charnes, \& Cooper, (1984). Efficiency measures under VRS was calculated by using DEAP 2.1 developed by Coelli (1996). 


\subsection{Exploring efficiency determinants}

Since many previous studies were used Tobit model in the second stage of efficiency analysis (Bjurek, Kjulin, \& Gustafsson, 1992; Ruggiero \& Vitaliano, 1999; Cinemre, Ceyhan, Bozoglu, Demiryurek, \& Kilic, 2006; Bravo-Ureta, Solís, López, Maripani, Thiam, Rivas, 2007; Gündüz, Ceyhan, \& Esengün, 2011; Luik, Viira, \& Värnik, 2014), Tobit model was used to explore the effects of socio-economic variables affected the services efficiency of beekeepers' associations in the second stage of efficiency analysis.

A Tobit regression of inefficiencies on potential determinants was used because the inefficiency scores are truncated at 0 and 1 . The Tobit model is specified as follows:

$$
\begin{array}{lll}
u_{i}>-\beta_{0}-\sum_{i=1}^{N} \beta_{i} X_{i} & \text { ise } & Y_{i j}=\beta_{0}+\sum_{i=1}^{N} \beta_{i} X_{i}+u_{i} \\
u_{i} \leq-\beta_{0}-\sum \beta_{i} X_{i} & \text { ise } \quad Y_{i j}=0
\end{array}
$$

Where $Y_{i j}$ was the measure of services efficiency for beekeepers' association i, $X_{i}$ were explanatory variables that influence the services efficiencies of the beekeepers' associations, $\mathrm{N}$ was the number of variables, ${ }^{\beta}$ were the parameters of the model and $u$ was the random error term.

The explanatory variables of services efficiency for beekeepers' association were the number of member, profile of managers, presence of marketing facilities for bee products, asset and personal cost in the model.

\section{Results and Discussions}

\subsection{General characteristics of beekeepers' association}

Research results showed that $92 \%$ of the Turkish beekeepers were recorded in beekeeping unions, while the rest were recorded in honey producers' union. 89\% of the member beekeepers were active in beekeepers' association. Average Turkish beekeepers' associations had 491 members and operated in for 8 years. In Turkey, the number of beekeepers that were member of beekeeping unions was 808 , on average, while that of honey producers' union was $87.78 \%$ of the beekeepers who were member of the Turkish beekeepers' association was itinerant beekeepers. The percentage of localized permanent member was 22\%. Beekeeping unions gained 54 new members per year, while that of honey producers' union was 13 (Table 1).

Table 1. The general profile of Turkish beekeepers' associations

\begin{tabular}{|l|c|c|c|c|c|c|c|c|c|}
\hline \multirow{2}{*}{} & \multicolumn{3}{|c|}{ BU } & \multicolumn{3}{c|}{ HPU } & \multicolumn{3}{c|}{ Turkey } \\
\cline { 2 - 12 } & mean & $\min$ & $\max$ & mean & $\min$ & $\max$ & $\operatorname{mean}$ & $\min$ & $\max$ \\
\hline Experience (years) & 10 & 3 & 12 & 5 & 1 & 17 & 8 & 1 & 17 \\
\hline Number of members (person) & 808 & 80 & 4321 & 87 & 20 & 225 & 491 & 20 & 4321 \\
\hline Localized permanent member (person) & 155 & 0 & 640 & 33 & 0 & 211 & 102 & 0 & 640 \\
\hline Itinerant member (person) & 653 & 0 & 4321 & 54 & 0 & 220 & 364 & 0 & 3681 \\
\hline
\end{tabular}

BU: Beekeeping unions, HPU: Honey producers' union 
When glancing at the physical asset of the Turkish beekeepers' associations, it was clear that the beekeeping unions was better comparing to honey producers' union. $5 \%$ of the total number of Turkish beekeeping unions conducted their activities in their own building, while the percentage of rented building and temporarily building were $88 \%$ and $7 \%$, respectively. The percentage of own, rented and temporarily building for honey producers' union were $5 \%, 71 \%$ and $24 \%$, respectively. Regarding the machinery park, $15 \%$ of the Turkish beekeepers' associations had honey filling machine. 14\% of the Turkish beekeepers' associations had the honey filling and packing plants. Table 2 presented the physical asset of the Turkish beekeepers' associations associated with the association type.

Table 2. Physical asset of the Turkish beekeepers' associations by association type

\begin{tabular}{|l|c|c|c|c|c|c|}
\hline & \multicolumn{2}{|c|}{ BU } & \multicolumn{2}{c|}{ HPU } & \multicolumn{2}{c|}{ Turkey } \\
\cline { 2 - 7 } & Frequency & $\%$ & Frequency & $\%$ & Frequency & $\%$ \\
\hline Research and Development Center & 1 & 1,4 & 0 & 0,0 & 1 & 0,8 \\
\hline Laboratory for bee health & 1 & 1,4 & 0 & 0,0 & 1 & 0,8 \\
\hline Laboratory for honey analysis & 1 & 1,4 & 0 & 0,0 & 1 & 0,8 \\
\hline Honey filling machine & 16 & 22,2 & 4 & 6,9 & 20 & 15,4 \\
\hline Honey filling and packing plants & 15 & 20,8 & 3 & 5,2 & 18 & 13,8 \\
\hline Burning machine & 2 & 2,8 & 0 & 0,0 & 3 & 2,3 \\
\hline Dough machine & 1 & 1,4 & 0 & 0,0 & 1 & 0,8 \\
\hline Heating boiler & 0 & 0,0 & 1 & 1,7 & 1 & 0,8 \\
\hline Cake machine & 10 & 13,9 & 4 & 6,9 & 14 & 10,8 \\
\hline Cake packing machine & 3 & 4,2 & 0 & 0,0 & 3 & 2,3 \\
\hline Carpenter & 1 & 1,4 & 0 & 0,0 & 1 & 0,8 \\
\hline Honeycomb machine & 3 & 4,2 & 0 & 0,0 & 3 & 2,3 \\
\hline Pollen drying machine & 1 & 1,4 & 1 & 1,7 & 2 & 1,5 \\
\hline Pollen packing machine & 1 & 1,4 & 0 & 0,0 & 1 & 0,8 \\
\hline Powder sugar mill & 1 & 1,4 & 0 & 0,0 & 1 & 0,8 \\
\hline Honey filtration machine & 1 & 1,4 & 0 & 0,0 & 1 & 0,8 \\
\hline
\end{tabular}

BU: Beekeeping unions, HPU: Honey producers' union

Based on the results of socio-economic analysis, education level of $76 \%$ of the managers of Turkish beekeepers' associations were college degree or more. The percentage of managers who has primary school graduation were 19\% for beekeeping unions and 31\% for honey producers' union (Table 3). 31\% of the managers had the ability of using foreign language. Common foreign languages were English $(60 \%)$, German $(10 \%)$ and Arabic $(15 \%)$. When focusing on the personal composition and characteristics, $21 \%$ of the 'Turkish beekeepers' associations employed secretary, while the percentage of employing retainer and office person were $12 \%$ and $3 \%$, respectively. The percentage of technical supervisor, director, agricultural engineer, veterinary and food engineer were $22 \%, 8 \%, 6 \%, 2 \%$ and $2 \%$, respectively. In addition, $4 \%$ of the Turkish beekeepers' associations benefited from the hired labor when the workload was heavy. The annual personal cost was $€ 25300$ and it was $€ 34000$ in BU and $€ 14000$ in HPU. 
Table 3. Education level of managers of the Turkish beekeepers' associations

\begin{tabular}{|l|c|c|c|c|c|c|}
\hline \multirow{2}{*}{ Education level } & \multicolumn{2}{|c|}{ BU } & \multicolumn{2}{c|}{ HBU } & \multicolumn{2}{c|}{ Turkey } \\
\cline { 2 - 7 } & Frequency & $\%$ & Frequency & $\%$ & Frequency & $\%$ \\
\hline Primary school & 14 & 19,2 & 18 & 31,1 & 31 & 24,4 \\
\hline College & 17 & 23,3 & 16 & 27,6 & 33 & 25,2 \\
\hline Vocational school & 18 & 24,7 & 9 & 15,5 & 27 & 20,6 \\
\hline Bachelor's degree & 21 & 28,8 & 13 & 22,4 & 34 & 26,0 \\
\hline Master of science & 3 & 4,1 & 2 & 3,4 & 5 & 3,8 \\
\hline Total & 73 & 100,0 & 58 & 100,0 & 131 & 100,0 \\
\hline
\end{tabular}

\subsection{Activities of the Turkish beekeepers' associations and relationship between associations and members}

Based on the research results, the services of Turkish beekeepers' associations were formed into four different group such as marketing services, education services, input supply services and R\&D activities. 15\% of the Turkish beekeepers' associations had the honey products marketing facility.

Table 4. Education programs and its participants associated with union type

\begin{tabular}{|c|c|c|c|c|c|c|}
\hline & \multicolumn{2}{|c|}{ BU } & \multicolumn{2}{|c|}{$\mathrm{HBU}$} & \multicolumn{2}{|c|}{ Turkey } \\
\hline \multicolumn{7}{|l|}{ Technical beekeeping } \\
\hline Number of union & 30 & 41,1 & 25 & 43,1 & 55 & 42,0 \\
\hline Number of participant & 10726 & 18,2 & 1954 & 38,9 & 12630 & 19,8 \\
\hline \multicolumn{7}{|l|}{ Queen bee rearing } \\
\hline Number of union & 15 & 20,5 & 5 & 8,6 & 20 & 15,3 \\
\hline Number of participant & 2223 & 3,8 & 380 & 7,6 & 2603 & 4,1 \\
\hline \multicolumn{7}{|l|}{ Organic beekeeping } \\
\hline Number of union & 6 & 8,2 & 7 & 12,1 & 13 & 9,9 \\
\hline Number of participant & 1666 & 2,8 & 695 & 13,8 & 2361 & 3,7 \\
\hline \multicolumn{7}{|l|}{ Bee products } \\
\hline Number of union & 12 & 16,4 & 5 & 8,6 & 17 & 13,0 \\
\hline Number of participant & 4504 & 7,6 & 553 & 11,0 & 5057 & 7,9 \\
\hline \multicolumn{7}{|l|}{ Bee bealth } \\
\hline Number of union & 19 & 26,0 & 8 & 12,8 & 27 & 20,6 \\
\hline Number of participant & 7326 & 12,4 & 515 & 10,2 & 7841 & 12,3 \\
\hline \multicolumn{7}{|l|}{ Record keeping } \\
\hline Number of union & 5 & 6,8 & 1 & 1,7 & 6 & 4,6 \\
\hline Number of participant & 1575 & 2,7 & 100 & 2,0 & 1675 & 2,6 \\
\hline \multicolumn{7}{|l|}{ Cooperation } \\
\hline Number of union & 4 & 5,5 & 2 & 3,4 & 6 & 4,6 \\
\hline Number of participant & 735 & 1,2 & 270 & 5,4 & 1005 & 1,6 \\
\hline \multicolumn{7}{|l|}{ Marketing } \\
\hline Number of union & 5 & 6,8 & 2 & 3,4 & 7 & 5,3 \\
\hline Number of participant & 1210 & 2,1 & 130 & 2,6 & 1340 & 2,1 \\
\hline \multicolumn{7}{|l|}{ Control and certification } \\
\hline Number of union & 7 & 9,6 & 2 & 3,4 & 9 & 6,9 \\
\hline Number of participant & 1218 & 2,1 & 190 & 3,8 & 1408 & 2,2 \\
\hline \multicolumn{7}{|l|}{ Quality } \\
\hline Number of union & 1 & 1,4 & 2 & 3,4 & 3 & 2,3 \\
\hline Number of participant & 120 & 0,2 & 160 & 3,2 & 280 & 0,4 \\
\hline
\end{tabular}


The percentage of association where they were marketing the honey was more in beekeeping unions $(22 \%)$ than that of honey producers' union $(7 \%) .66 \%$ of the Turkish beekeepers' associations conducted education activities to increase their members' technical capacity. It varied associated with the type of associations and it was $74 \%$ in beekeeping unions, while that of honey producers' union was $57 \%$. In general, education programs for beekeepers oriented to technical dimension of beekeeping such as organic beekeeping, bee products, bee health, honey quality etc. in Turkey. However, the programs related to economic dimension of beekeeping such as record keeping, marketing, certification etc. was not common. Education programs held for beekeepers were depicted in Table 4. Regarding the R\&D activities, it was clear that the Turkish beekeepers' associations was weak on R\&D activities. The only $7 \%$ of the Turkish beekeepers' associations had the improvement studies. Similarly, the experience of project of the Turkish beekeepers' associations was unsatisfactory level. $29 \%$ of the Turkish beekeepers' associations had the national level project experience, while that of international ones was only $5 \%$. Input supply was the another services of beekeeping association in Turkey. Beekeeping associations supplied the queen bee, bee hive, cake and honeycomb to their members. The input supply services of beekeeping unions were more satisfactory comparing to honey producers' union due to their strong infrastructure $(\mathrm{p}<0,01) .47 \%$ of the beekeeping unions presented their services to non-member beekeepers, while the percentage was $36 \%$ for honey producers' union. Based on the research results, $70 \%$ of the Turkish beekeepers were satisfied from the services of Turkish beekeeping association. The satisfaction level of beekeepers varied associated with the scale of the beekeeping association. The satisfaction level of medium and large size beekeeping association were more than that of small ones.

\subsection{Economic structure of the Turkish beekeepers' associations}

The main income source of Turkish Beekeepers' association was annual membership fee by $57 \%$. Product sales $(19 \%)$ and plate and barcode sales $(11 \%)$ followed it. The percentage of product sales in total income of association was $20 \%$ in beekeepers' union, while that of honey producers' union was $11 \%$. Regarding the cost structure, the most magnificent cost item was labor cost by $20 \%$. It was followed by product purchasing cost by $15 \%$ and manager's payment by $13 \%$. On average, Turkish beekeepers' association gained 1,32 Turkish liras from one Turkish lira purchasing. It was 1,36 Turkish Liras for beekeepers' union and 1,02 Turkish Liras for honey producers' union. It was clear based on the results of the economic analysis that economic situation of beekeepers' union was better than that of honey producers' union (Table 4).

Table 4. Revenue and cost of Turkish beekeepers' association associated with union type (⿺)

\begin{tabular}{|l|c|c|c|c|c|c|c|}
\hline & \multicolumn{9}{|c|}{ BU } & \multicolumn{3}{c|}{ HBU } & \multicolumn{2}{c|}{ Turkey } \\
\hline Revenue & Mean & Std. deviation & Mean & Std. deviation & Mean & Std. deviation \\
\hline & 22079,88 & 8941,42 & 1479,74 & 714,71 & 13801,96 & 5666,70 \\
\hline Product sales ** & 8667,95 & 1153,59 & 1103,79 & 141,36 & 5649,77 & 949,68 \\
\hline $\begin{array}{l}\text { New member entrance } \\
\text { allowance*** }\end{array}$ & 61861,58 & 20017,16 & 8925,86 & 1913,37 & 40785,52 & 12514,25 \\
\hline Annual member allowance **
\end{tabular}




\begin{tabular}{|c|c|c|c|c|c|c|}
\hline Plate and barcode sales $* * *$ & 12175,64 & 3315,73 & 1980,82 & 328,95 & 8126,63 & 1776,62 \\
\hline $\begin{array}{l}\text { Other revenues (Grants, } \\
\text { honey filling and packing, } \\
\text { input sales) } * *\end{array}$ & 5170,10 & 1890,36 & 376,55 & 172,08 & 3245,10 & 1090,52 \\
\hline Total revenue $* * *$ & 109955,17 & 15885,76 & 13866,76 & 2701,57 & 71608,98 & 17588,88 \\
\hline \multicolumn{7}{|l|}{\begin{tabular}{|l|} 
Expenditure \\
\end{tabular}} \\
\hline Raw material $* * *$ & 12569,23 & 5718,41 & 1163,28 & 660,40 & 7999,01 & 3271,03 \\
\hline Allowance $* * *$ & 3628,39 & 586,08 & 284,60 & 19,78 & 2286,43 & 205,55 \\
\hline Managers' salary *** & 10076,00 & 4300,00 & 2229,31 & 577,19 & 6986,47 & 1089,07 \\
\hline $\begin{array}{l}\text { Plate and barcode purchasing } \\
* * *\end{array}$ & 6345,12 & 1124,00 & 1363,53 & 187,42 & 4381,71 & 586,58 \\
\hline Labor cost $* * *$ & 17004,15 & 1764,25 & 2006,66 & 1056,75 & 11013,05 & 1395,32 \\
\hline $\begin{array}{l}\text { Cost of rent, energy, } \\
\text { communication and cleaning ** }\end{array}$ & 10285,13 & 2006,80 & 3078,79 & 716,42 & 7487,09 & 188,88 \\
\hline $\begin{array}{l}\text { Laboratory charge and R\&D } \\
\text { payment }\end{array}$ & 1415,00 & 523,36 & 88,45 & 19,65 & 881,68 & 450,97 \\
\hline Transportation cost $* *$ & 6118,59 & 1410,67 & 1495,34 & 611,72 & 4305,19 & 1036,66 \\
\hline Marketing cost $* *$ & 4652,56 & 904,55 & 405,17 & 108,42 & 2949,62 & 550,33 \\
\hline Hospitality cost $* *$ & 2551,16 & 370,93 & 531,98 & 88,07 & 1754,55 & 145,78 \\
\hline $\begin{array}{l}\text { Other expenditures } \\
\text { depreciation, tax, insurance } \\
\text { etc.) } * *\end{array}$ & 6272,76 & 1491,20 & 823,83 & 327,17 & 4099,67 & 2079,09 \\
\hline Total expenditure $* * *$ & 80918,09 & 16218,54 & 13470,94 & 4378,90 & 54144,47 & 9750,68 \\
\hline $\begin{array}{l}\text { Total revenue - total } \\
\text { expenditure }\end{array}$ & 29037,08 & 14476,47 & 395,82 & 401,06 & 17464,51 & 8259,07 \\
\hline $\begin{array}{l}\text { Total revenue / Total } \\
\text { expenditure } *\end{array}$ & 1,36 & 0,26 & 1,03 & 0,18 & 1,32 & 0,30 \\
\hline
\end{tabular}

$*$, ** and ${ }^{* * *}$ reflects that the difference between the means of beekeepers' union and honey producers' union for the related variable are statistically significant at the probability level of $10 \%, 5 \%$ and $1 \%$, respectively.

(1) One Turkish (€) lira equaled to 2,67 US dollar and 3 euro.

\subsection{Services efficiency of 'Turkish beekeepers' association}

Efficiency analysis results showed that services efficiency score of Turkish beekeepers' association was 0,62, on average in Turkey. Services efficiency score of beekeepers' union was better than that of honey producers' union $(p<0.05)$ (Table 5). $11 \%$ of the Turkish beekeepers' association were efficient, while the rest were inefficient. The percentage of efficient association for beekeepers' union and honey producers' union were $15 \%$ and $6 \%$, respectively (Table 6 ).

Table 5. Efficiency scores of Turkish beekeepers' association and some basic characteristics

\begin{tabular}{|l|c|c|c|c|}
\hline & $\begin{array}{c}\text { Services efficiency } \\
\text { score } *\end{array}$ & $\begin{array}{c}\text { Services score } \\
*\end{array}$ & $\begin{array}{c}\text { Number of members } \\
\text { (person) } * *\end{array}$ & $\begin{array}{c}\text { Optimum number of } \\
\text { member (person) } * *\end{array}$ \\
\hline Beekeepers' union & $0,63 \pm 0,01$ & $16,14 \pm 0,12$ & $808 \pm 92$ & $1274 \pm 280$ \\
\hline $\begin{array}{l}\text { Honey producers' } \\
\text { union }\end{array}$ & $0,60 \pm 0,02$ & $0,27 \pm 0,12$ & $87 \pm 7$ & $484 \pm 264$ \\
\hline
\end{tabular}

* and ** reflects that the difference between the means of beekeepers' union and honey producers' union for the related variable are statistically significant at the probability level of $10 \%$ and $5 \%$, respectively. 
Table 6. The distribution of the efficient and inefficient Turkish beekeepers' association

\begin{tabular}{|l|c|c|c|}
\hline \multirow{2}{*}{} & \multicolumn{2}{|c|}{ Efficiency group } & \multirow{2}{*}{ Total } \\
\cline { 2 - 3 } & Inefficient & Efficient & \\
\hline Beekeepers' union & 63 & 11 & 74 \\
\hline Honey producers' union & 55 & 3 & 58 \\
\hline Total & 118 & 14 & 132 \\
\hline
\end{tabular}

* The difference between the beekeepers' union and honey producers' union was statistically significant at the probability level of $10 \%\left(X^{2}=3,222\right)$.

Based on the results of the second stage of the efficiency analysis, the most important variables affected the services efficiency were managers' profile and the number of member. When the number of member and the qualification of the managers were increasing, services efficiency of 'Turkish beekeepers' association was increasing $(\mathrm{p}<0.01)$. The other variables that positively affected the efficiency were presence of building and having marketing facility $(\mathrm{p}<0.05)$. Having unsuitable labor composition and uncontrollable expenditure were the other variables that negatively affected the service efficiency (Table 7). Comparable analysis revealed that the efficiency score was 0,98 for efficient association, while that of inefficient ones was 0,57 . The number of member and the level of organization culture in efficient association were more satisfactory level than that of inefficient association. Efficient associations were managed by more skillful managers and they had enough personal and good infrastructure. The profitability level of efficient association that served the more facilities to their members and focused on economic issues in education programs was more than inefficient ones. In addition, services portfolio of efficient association was wider than comparing to inefficient one (Table 8).

Table 7. The determinants of service efficiency for Turkish beekeepers' association

\begin{tabular}{|l|c|c|}
\hline Variables & Coefficient & Standard error \\
\hline Constant & $0,4574 * * *$ & 0,0195 \\
The number of member (person) & $0,0029 * * *$ & 0,0001 \\
Non-current asset (Turkish Lira) & $0,0014 * *$ & 0,0007 \\
The profile of managers & $0,0706 * * *$ & 0,0226 \\
Number of personal (person) & $-0,0131 *$ & 0,0079 \\
Number of member who supplied raw material & $0,0019 *$ & 0,0001 \\
& $0,118 * * *$ & 0,008 \\
Error & 0,535 & \\
$\mathrm{R}^{2}$ & $76,05^{* *}$ & \\
LR test statistics & & \\
$*$ statistically significant at the probability level of 10\%, $* *$ statistically significant at the \\
probability level of $5 \%, * * *$ statistically significant at the probability level of $1 \%$.
\end{tabular}

Table 8. Some socio-economic characteristics of efficient and inefficient beekeepers' association

\begin{tabular}{|l|r|r|r|r|}
\hline & \multicolumn{3}{|l|}{ Inefficient association } & Efficient association \\
\cline { 2 - 5 } & Mean & Standard error & Mean & Standard error \\
\hline Number of association (unit) & 118 & -14 & $-0,01$ \\
\hline Service efficiency score *** & 0,57 & 0,01 & 0,98 & 0,01 \\
\hline Number of member (person) $*$ & 469 & 64 & 792 & 159 \\
\hline
\end{tabular}




\begin{tabular}{|c|c|c|c|c|}
\hline Revenue/Expenditure *** & 2,20 & 0,27 & 6,77 & 3,48 \\
\hline White collar personal (person) & 0,70 & 0,12 & 1,07 & 0,37 \\
\hline Blue collar personal (person) & 0,91 & 0,09 & 1,07 & 0,34 \\
\hline Experience (year) $* *$ & 7,84 & 0,33 & 9,93 & 0,82 \\
\hline Number of educated member (person) & 1995 & 718 & 1769 & 407 \\
\hline Number of member buying beehive (person) & 251 & 85 & 325 & 75 \\
\hline Number of member buying cake (person) & 222 & 67 & 550 & 450 \\
\hline Number of member used credit (person) & 82 & 24 & 171 & 164 \\
\hline Number of member buying honeycomb (person) & 337 & 121 & 589 & 462 \\
\hline Revenue from product sales (Turkish lira) $*$ & 9125,00 & 2601,082 & 075,00 & 7026,90 \\
\hline
\end{tabular}

\section{Conclusions}

Under the light of the results of the study, economic performance and the service efficiency of Turkish beekeepers' association was unsatisfactory level. Turkish beekeepers' association should be managed by more professional managers in order to solve the structural and economic problems of associations. Participatory approach will make members more active than the past and this approach will increase the service efficiency of beekeepers' association. Keeping the basic record in the beekeepers' association and developing information management system would accelerate the efficiency improving in Turkey. Giving up the conventional function that is helping the implementation of government policy and focusing on basic functions may increase the service efficiency of Turkish beekeepers' association. Turkish beekeepers' association should be more active in marketing of honey products by using marketing strategies such as making brand etc. and benefit the national or international financial funds via research projects to transform the structure of the beekeepers' associations in Turkey.

Supporting the infrastructure of the Turkish beekeepers' association and optimizing the number of member may accelerate the improvement of service efficiency. Of course, the role of government should be redesigned to transform the beekeeping industry. Developing the control standards in input and output markets and increasing the quality of relationship among the beekeepers' association and all actors in beekeeping industry may contribute the solving the problems of sector.

\section{Acknowledgement}

This paper is based on the findings of the research, which was financially supported by TÜBİTAK, with the project number of $113 \mathrm{O} 541$. We are immensely grateful to TÜBİTAK for its valuable support. 


\section{References}

Agera, S.I. (2011). Role of Beekeeping In The Conservation of Forests. Global Journal of Agricultural Sciences, 10(1), 27-32.

Aiyeloja, A.A, Popoola L. and Ogunjinmi, A.A. (2010). Economic Analysis of Honey Production in Southwest Nigeria. Asia-Pacific Journal of Rural Development, 20(1), 51-60.

Banker, R. D. Charnes, A. and Cooper, W. W. (1984). Some Models for Estimating technical and Scale Efficiencies in Data Envelopment Analysis. Management Science, 30(9), 1078-1092.

Barlovic, N., Kezic, J., Benedic, O.N., \& Grgic, Z. (2009). Economic efficiency of beekeeping in Croatia. Agriculturae Conspectus Scientificus, 74(1), 51-54.

Bjurek, H. Kjulin, U \& Gustafsson, B. (1992). Efficiency, productivity and determinants of inefficiency at public day care centers in Sweden. Scandinavian Journal of Economics, 94 (Supplement), 173-187.

Bravo-Ureta, B.E., Solís, D., López, VHM. Maripani, JF., Thiam, A., Rivas, T. (2007). Technical efficiency in farming: a meta-regression analysis, Journal of Productivity Analysis, 27, 57-72.

Ćejvanović, Z., Grgic Z., Maksimović, A. and Bicani, D. (2011). Assumptions of Economic Model for Sustainable Productions of Beekeeping in the Bosnia and Hercegovina. Journal of Agricultural Science and Technology, 5 (4): 481-485.

Charnes, A. Cooper, W.W., Rhodes, E. (1978). Measuring the efficiency of decision making units. European Journal of Operational Research. 2 (4), 429 - 444.

Cinemre, H.A., Ceyhan,V., Bozoglu, M., Demiryurek, K. and Kilic, O. (2006). The cost efficiency of trout farms in the Black Sea region. Turkey, Aquaculture, 251, 324-332.

Coelli, T.J. (1996). A Guide to DEAP Version 2.1: A Data Envelopment Analysis (Computer) Program. CEPA Working Paper 96/8. Department of Econometrics. University of New England Armidale NSW Australia.

Coelli, T.J., Rao, D.S.P., O'Donnell, C.J. and Battese, G.E. (2005). An Introduction to Efficiency and Productivity Analysis. 2nd ed. Springer, New York.

Cakal, M.A. (2013). Kuzeydogu Anadolu Bölgesi Arıcllk ve Ar1 Urünleri Sektörü. Kuzeydogu Anadolu Kalkınma Ajansı.

FAO. (2014, 4 1). Date of 4 1, 2014 FAO: http://faostat.fao.org/site/569 /DesktopDefault.aspx?PageID=569\#ancor

Farrell, M.J. (1957). The Measurement of Productive Efficiency. Journal of the Royal Statistical Society, 120(3),253-290.

Gündüz, O. Ceyhan, V. and Esengün, K. (2011). Measuring the technical and economic efficiencies of the dry apricot farms in Turkey. Journal of Food, Agriculture \& Environment, 9 (1), 319-324.

Kekeçoglu, M., Gürcan, E. K., Soysal, M. I. (2007). Türkiye Ar1 Yetiş,tiriciliginnin Bal Ưretimi Bakımından Durumu. Tekirdag Ziraat Fakultesi Dergisi, 4(2), 227-236.

Kizilaslan, H., \& Kizilaslan, N. (2007). Factors Affecting Honey Production in Apiculture in Turkey. Journal of Applied Sciences Research, 3(10), 983-987.

Kutlu, M.A. (2014). Gaziantep Ili Arıcılık Düzeyinin Saptanması, Sorunları ve C,özüm Yolları. Türk Tarım ve Doğa Bilimleri Dergisi, 1(4), 481-484.

Laate, E.A. (2013). Economics of Beekeeping in Alberta. Alberta Agriculture and Rural Development, Canada.

Luik, H. Viira, A.H.,Värnik, R. (2014). Using the information about dairy herd's genetic level and milk quality in explaining the technical efficiency of Estonian dairy farms: a two-stage (DEA and Tobit) approach. EAAE 2014 Congress 'Agri-Food and Rural Innovations for Healthier Societies', August 26 to 29, Ljubljana, Slovenia.

Masuku, M.B. (2013). Socioeconomic analysis of beekeeping in Swaziland: A case study of the Manzini Region, Swaziland. Journal of Development and Agricultural Economics, 5(6), 236-241.

Mogni, F., Senesi, S., Palau, H., Vilella, F. (2010). The Argentine beekeeping sector:description within the sustainable development framework, International Food and Agribusiness Management Association, 20th Annual World Forum and Symposium Boston, Massachusetts, USA. June 19-22.

Pocol, C. B. (2011). Modelling the honey consumption behaviour in Romania by using socio-demographic determinants. African Journal of Agricultural Research, 6(17), 4069-4080. 
Pocol, C., \& Ilea, M. (2008). The Development Of Local Products in Romania: A Case Study of Honey. Lucrari Stiintifice Seria I Management Agricol, 13(2), 153-160.

Popa, A. A., \& Pocol, C. B. (2011). A complex model of factors that influence entrepreneurship in the beekeeping sector. Bulletin UASVM Horticulture, 68(2), 188-195.

Popescu, A. (2013). Research Concernig Apiary Size, Honey Yield And Beekeepers' Income In Teleorman County Scientific Papers Series Management. Economic Engineering in Agriculture and Rural Development, 13(1), 293-299.

Ruggiero, J., Vitaliano, D.F. (1999). Assessing the efficiency of public schools using data envelopment analysis and frontier regression. Contemporary Economic Policy 17 (3), 321-331.

Saner, G., Yücel, B., Yercan, M., Karaturhan, B., Engindeniz, S., C,ukur,F., Kösoglu, M. (2011). Organik Ve Konvansiyonel Bal Uretiminin Teknik ve Ekonomik Yönden Geliş,irilmesi ve Alternatif Pazar Olanaklarının Saptanması Uzerine Bir Araș,ırma: Tzmir Ili Kemalpaşa Ilçesi Örneğ̈, Tepge Yayın No: 195, Ankara.

Seven I., \& Yeninar, H. (2010). Elazığ yöresindeki arıcılık ișletmelerinin sosyo- ekonomik yapısının belirlenmesi, e-Journal of New World Sciences Academy Veterinary Sciences, 5 (1), $36-46$.

Singh, B., \& Saxena, D. (2009). Diagnostic Study of Chamoli District Beekeping SMEs Cluster. Pranjana, JulDec, 12(2), 105-116.

Uzundumlu, A.S., Aksoy,A. Isş1k, H.B. (2011). Arıcllk Işletmelerinde Mevcut Yapı ve Temel Sorunlar; Bingöl Ili Önnegi. Atatürk Universitesi Ziraat Fakultesi Dergisi, 42 (1), 49-55.

Yahaya, A.T. \& Usman, L. (2008). Economic Analysis of Katsina State's Beekeeping Development Project. Savannah Journal Of Agriculture, 3, 69-76. 